\title{
KEANEKARAGAMAN BULU BABI (Echinoidea) PADA KAWASAN LAMUN DI PERAIRAN DESA LANGARA, KECAMATAN WAWONII BARAT KABUPATEN KONAWE KEPULAUAN
}

\section{Diversity Of Sea Urchins (Echinoidea) In Seagrass Areas In The Waters Of The Village of Langara, West Wawonii District, Islands Konawe District}

\author{
La Ode Sadam $A^{1}$, Emiyarti $^{2}$, Ira $^{3}$ \\ ${ }^{1}$ Mahasiswa Jurusan Ilmu Kelautan, \\ Fakultas Perikanan dan Ilmu Kelautan, Universitas Halu Oleo. \\ Jl. H.E.A Mokodompit Kampus Hijau Bumi Tridharma Anduonohu Kendari 93232, Telp/Fax: (0401) 3193782 \\ ${ }^{2}$ Surel: emiyarti@ymail.com \\ ${ }^{3}$ Surel: bahari_00@yahoo.co.id
}

\begin{abstract}
Abstrak
Bulu babi merupakan hewan laut yang termasuk dalam filum Echinodermata dalam kelas Echinoidea. Cangkang dan gonad bulu babi diketahui memiliki nilai ekonomi yang tinggi. Penelitian ini dilaksanakan pada bulan November Desember 2018 dan bertujuan untuk mengetahui jenis bulu babi di Perairan Desa Langara Wawonii Barat dan mengetahui struktur komunitas bulu babi di Perairan Desa Langara Wawonii Barat. Pengambilan data lamun dan bulu babi dilakukan dengan menggunakan transek kuadrat dengan cara menarik transek garis sepanjang 100 meter secara tegak lurus ke arah laut. Pengambilan data dilakukan pada saat air surut atau menjelang surut terendah. Mulia dari titik nol diletakkan transek kuadrat 1 x 1 meter dengan jarak 10 meter, sedangkan jarak untuk tiap transek garis adalah 20 meter dengan 3 kali pengulangan. Dari hasil penelitian di Perairan Desa Langara didapatkan tujuh jenis bulu babi dari empat famili yaitu bulu babi jenis D. savignyi, E. calamaris, E. mathaei, T. gratilla, A. crissipina, D. setosum, T. toreumaticus. Hasil kepadatan bulu babi yang di dapatkan yaitu tertinggi terdapat di stasiun III pada bulan terang dengan nilai 9,03ind $/ \mathrm{m} 2$ dan kepadatan terendah terdapat pada stasiun II pada bulan gelap, dengan nilai 2,57ind $/ \mathrm{m} 2$ dimana keanekaragaman bulu babi selama penelitian juga tertinggi terdapat pada stasiun I yakni 1.64, serta terendah terdapat pada stasiun stasiun III yaitu 1.38 dan Keseragaman bulu babi selama penelitian, tertinggi terdapat pada stasiun II yakni 2.00 serta keseragaman terendah pada stasiun III yaitu 1.77. Dominansi bulu babi yang tertinggi terdapat pada stasiun III yakni 0.3 dan terendah terdapat pada stasiun I dan II yaitu 0.2.
\end{abstract}

Kata kunci : Bulu babi, jenis bulu babi, kepadatan, keanekaragaman, keseragaman, dominansi

\begin{abstract}
Sea urchins are marine animals that are included in the phylum Echinoderms in the Echinoidea class. Shells and gonads of sea urchins are known to have high economic value. This research was conducted in November - December 2018 and aimed to determine the type of sea urchins in the Langara Wawonii West Waters and to know the structure of the sea urchins in the waters of West Langara Wawonii Village. Retrieval of seagrass and sea urchin data is done by using quadratic transects by drawing a line transect along 100 meters perpendicular to the sea. Data retrieval is done at low tide or before the lowest ebb. Noble from the zero point is placed a transect squared 1 x 1 meter with a distance of 10 meters, while the distance for each line transect is 20 meters with 3 repetitions. From the results of the research in the waters of Langara Village there were seven types of sea urchins from four families, namely D. savignyi, E. calamaris, E. mathaei, T. gratilla, A. crissipina, D. setosum, T. toreumaticus. The results of the density of sea urchins obtained were highest at station III in the bright month with a value of 9.03ind $/ \mathrm{m} 2$ and the lowest density was at station II in the dark months, with a value of 2.57 ind / $\mathrm{m} 2$ where the highest diversity of sea urchins was found at station I which is 1.64 , and the lowest is at station station III, namely 1.38 and uniformity of sea urchins during the study, the highest is at station II which is 2.00 and the lowest uniformity at station III is 1.77 . The highest dominance of sea urchins is found at station III which is 0.3 and the lowest is found in stations I and II, which are 0.2 .
\end{abstract}

Key words : sea urchins, types, density, diversity, similarity, dominance.

\section{Pendahuluan}

Wawonii merupakan sebuah pulau berpenghuni yang terletak digugusan perairan laut Banda dan merupakan bagian integral dari wilayah administratif Kabupaten Konawe Kepulauan. Pulau ini memiliki keanekaragaman hayati laut yang berlimpah terutama pada ekosistem pesisirnya yang salah satunya adalah ekosistem lamun dimana banyak organisme Echinodermata yang berasosisasi di lamun salah satunya bulu babi. Organisme tersebut memanfaatkan lamun sebagai tempat mencari makan, memijah maupun menjadikannya sebagai daerah asuhan. 
Lamun adalah tumbuhan berbunga yang dapat tumbuh dengan baik pada lingkungan laut dangkal. Semua lamun adalah tumbuhan berbiji satu (monokotil) yang mempunyai akar, daun, bunga dan buah seperti halnya dengan tumbuhan berpembuluh yang tumbuh di darat. Lamun senantiasa membentuk satu ekosistem di laut yang dapat terdiri dari satu spesies, banyak terdapat di daerah tropis yang selanjutnya disebut padang lamun. Ekosistem padang lamun merupakan ekosistem pesisir yang ditumbuhi oleh lamun sebagai vegetasi yang dominan serta mampu hidup secara permanen di bawah permukaan air laut, Echinodermata merupakan organisme yang hidup pada ekosistem padang lamun, hal ini di karenakan ekosistem ini kompleks dan mempunyai fungsi dan manfaat yang sangat panting bagi habitat organisme dan perairan wilayah pesisir (Tangke dan Umar, 2010).

Echinodermata yaitu hewan yang tidak bertulang belakang dan memiliki duri pada permukaan kulitnya. Echinodermata dapat ditemui hampir semua ekosistem laut. Namun ekosistem yang paling tinggi terdapat pada di zona intertidal. Hal ini dikarenakan pada masing-masing daerah. Intertidal pantai berbatu yang tersusun dari bahan keras merupakan daerah yang paling padat organismenya dan mempunyai keaneka-ragaman terbesar baik untuk spesies hewan maupun tumbuhan. Diketahui bahwa komunitas hewan Echinodermata di alam bebas memiliki ukuran populasi yang tidak sama kerena dalam komunitas itu terjadi interaksi spesies yang tinggi (Katili dan Abubakar sidik, 2011).

Bulu babi (sea urchins) merupakan hewan laut yang termasuk dalam filum Echinodermata dalam kelas Echinoidea. Secara fisik bulu babi memiliki duri-duri yang terdapat pada seluruh tubuhnya yang berfungsi sebagai alat gerak serta alat pertahanan diri. Bulu babi banyak ditemukan pada ekoistem padang lamun karena organisme tersebut memanfaatkan lamun sebagai daerah pertahanan, tempat mencari makan, memijah maupun menjadikannya sebagai daerah asuhan dan lain-lain( Aswandy $d k k$., 2000).

Bulu babi sebagai organisme paling populer untuk mempelajari biologi reproduksi, embriologi, toksikologi, regulasigen dan biologi evolusion. Cangkang, dan gonad diketahui memiliki nilai ekonomi yang tinggi. Cangkang dan duri dapat digunakan sebagai hiasan, pupuk organik, pewarna, dalam bidang kesehatan untuk pengobatan penyakit memiliki potensi sebagai anti kanker, anti tumor, antibiotik dan antimikroba. Gonadnya dapat dijadikan sebagai sumber pangan karena mengandung 28 macam asam amino, vitamin B kompleks, vitamin A dan mineral, asam lemak tak jenuh omega-3, omega-6, dan omega 9. Di luar negeri gonad bulu babi menjadi makanan popular dengan nilai perdagangan yang baik, dipasarkan dalam bentuk produk segar, produk beku, produk asin, produk kering, maupun produk kalengan berupa pasta fermentasi. Di Indonesia dikonsumsi dalam keadaan segar atau dalam keadaan yang sudah dimasak seperti digoreng, dibakar dan dikukus (Tupan dan Silaban, 2017).

Dengan melihat kelimpahan bulu babi di Desa Langara maka perlu dilakukan penelitian ini tentang bagaimana keanekaragaman bulu babi pada kawasan lamun di Perairan Langara Kecamatan Wawonii Barat Kabupaten Konawe Kepulauan.

\section{Bahan dan Metode}

Penelitian ini dilaksanakan pada Bulan November - Desember 2018 di Perairan Desa Langara, Kecamatan Wawonii Barat, Kabupaten Konawe Kepulauan. Analisis tekstur substrat yang dilakukan di Laboratorium Dasar Kimia Analitik Universitas Halu Oleo, Kendari. Peta lokasi penelitian di Perairan Desa Langara, Konawe Kepulauan dapat di lihat pada Gambar 1.

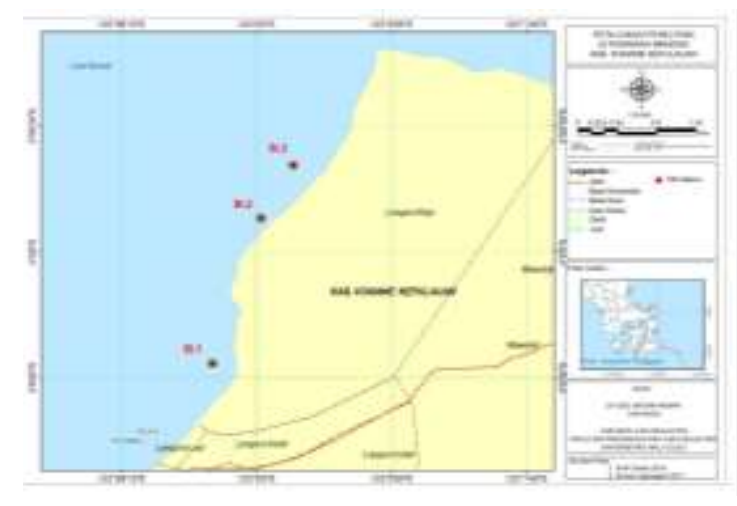

Gambar 1. Peta Lokasi Penelitian Perairan Wawonii, Konawe Kepulauan 
Prosedur penelitian meliputi survey pendahuluan, penentuan stasiun penelitian, pengambilan data Lamun dan Bulu babi, pengukuran kualitas perairan dan pengambilan sampel sedimen. Tahap survey pendahuluan dilakukan untuk mengetahui kondisi lokasi penelitian, penentuan titik stasiun dalam pengambilan sampel dan persiapan peralatan yang akan digunakan di lapangan.

Berdasarkan survey pendahuluan yang telah dilakukan, lokasi stasiun penelitian dan penentuan stasiun penelitian dilakukan berdasarkan kepadatan lamun dan sabaran bulu babi dengan metode Purposive sampling sebagai berikut : Stasiun I, terletak dibagian Barat Desa Langara, berada pada titik koordinat $\left(123^{\circ} 0\right.$ ' 13,70 ” BT - $3^{\circ} 59$ ' 25,50” LS). Stasiun ini berada pada kondisi lamun yang memiliki persen penutupan yang rapat, stasiun ini dekat dengan pemukiman warga sehingga menjadi tempat akses kapal nelayan pancing keluar masuk dari desa dan juga tempat penangkapan ikan bagi warga desa Langara. Tekstur substrat di stasiun ini yaitu berpasir kasar. Stasiun II, terletak dibagaian Barat Desa Langara dan dekat dengan hutan mangrove, berada pada titik koordinat $\left(123^{\circ}\right.$ 0' 1,69" BT - $3^{\circ} 59^{\prime} 46,5^{\prime \prime}$ LS). Stasiun ini berada pada kondisi lamun yang memiliki persen penutupan yang rapat karena memiliki dasar perairan yang landai. Tekstur substrat di stasiun ini yakni berpasir sedang.

Stasiun III, terletak dibagian Barat Desa Langara, berada pada titik koordinat

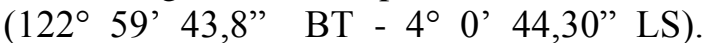
Stasiun ini berada pada kondisi lamun yang persen penutupannya sedang. Stasiun ini dekat dengan pantai pasir putih dan merupakan tempat rekreasi masyarakat. Terkstur substrat di stasiun ini yaitu berpasir halus.

Lokasi penentuan titik untuk penelitian ini hanya diambil tiga titik koordinat karena berdasarkan survey awal yang telah dilakukan yaitu berdasarkan tingkat kepadatan lamun dan keberadaan bulu babi yang mewakili semua lokasi yang akan dilakukan penelitan yang mana lokasi tersebut mewakili semua ekosistem lamun yang ada di wilayah tersebut.

Pengambilan data lamun dan bulu babi dilakukan dengan menggunakan transek kuadrat. Transek garis sepanjang 100 meter yang ditarik tegak lurus terhadap garis pantai ke arah laut, yang dilakukan pada saat air surut atau menjelang surut terendah. Mulai dari titik nol diletakkan transek kuadrat $1 \times 1$ meter dengan jarak 10 meter, sedangkan jarak untuk tiap transek garis adalah 20 meter dengan 3 kali pengulangan.

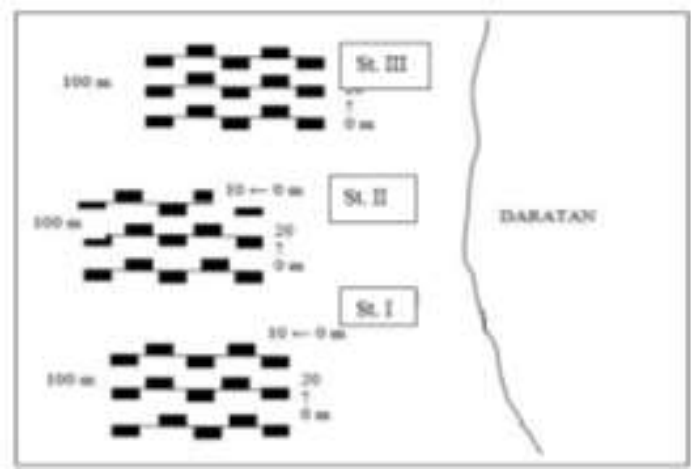

Gambar 2. Sketsa pengambilan data

Pengukuran kualitas perairan dilakukan secara insitu yang bertujuan untuk mengetahui kondisi perairan habitat bulu babi yang meliputi pengukuran suhu, salinitas, kecepatan arus, $\mathrm{pH}$, kecerahan,tekstur substrat dan kedalaman perairan.

\section{Analisis Data}

Menurut Steven., $d k k$ (2014), kepadatan bulu babi dapat dihitung dengan menggunakan rumus:

$K_{i}=\frac{n_{i}}{A}$

Dimana :

$\mathrm{Ki}=$ Kepadatan jenis i (individu/m2)

ni $=$ Jumlah jenis $\mathrm{i}$ yang ditemukan (individu)

A $\quad=$ Luas kuadran $\left(\mathrm{m}^{2}\right)$

Keanekaragaman spesies dapat dikatakan sebagai indikasi banyaknya jenis dan bagaimana penyebaran jumlah individu pada setiap jenis dan lokasi sampling. Untuk menentukan keanekaragaman dihitung dengan menggunakan formula ShannonWeaver (Odum, 1993), sebagai berikut :

$\mathrm{H}^{\prime}=-\sum \mathrm{Pi} \operatorname{Ln} \mathrm{Pi} ; \mathrm{Pi}=\mathrm{ni} / \mathrm{N}$

Dimana:

H' = Indeks Keanekaragaman Jenis

$P i=\frac{n i}{N}$ (Proporsi jenis ke-i)

$\mathrm{ni}=$ Jumlah individu jenis ke-i

$\mathrm{N}$ = Jumlah total individu 
Kisaran stabilitas perairan berdasarkan indeks perairan tersaji dalam Tabel 2 berikut:

Tabel 1. Kisaran Stabilitas Perairan

Berdasarkan Indeks Keanekaragaman

\begin{tabular}{|c|l|}
\hline $\begin{array}{c}\text { Kisaran } \\
\text { Stabilitas }\end{array}$ & \multicolumn{1}{|c|}{ Keanekaragaman } \\
\hline $0<\mathrm{H}^{\prime} \leq 1$ & Rendah (tidak stabil) \\
\hline $1<\mathrm{H}^{\prime} \leq 3$ & Sedang \\
\hline $\mathrm{H}^{\prime}>3$ & Tinggi (Stabil) \\
\hline
\end{tabular}

Keseragaman dapat dikatakan sebagai keseimbangan, yaitu komposisi individu tiap jenis yang terdapat dalam suatu komunitas. Untuk menghitung keseragaman jenis dapat dihitung dengan menggunakan rumus Evennes (Odum, 1993) berikut :

$E=\frac{H^{\prime}}{H_{\max }}$

Keterangan :

$\mathrm{E}=$ Indeks Keseragaman

$\mathrm{H}^{\prime}=$ Indeks Keanekaragaman

$\mathrm{H} \max =$ Jumlah Jenis Organisme $(\ln \mathrm{S})$

Dimana :

$\mathrm{E}<0,4$ : Tingkat keseragaman populasi kecil

$0,4<\mathrm{E}<0,6$ : Tingkat keseragaman populasi sedang. $\mathrm{E}>0,6$ : Tingkat keseragaman populasi besar.

Untuk menghitung indeks dominansi digunakan rumus Odum, (1993) sebagai berikut :

$\mathrm{D}=(\mathrm{ni} / \mathrm{N})^{2}$

Keterangan :

$\mathrm{D}=$ Indeks Dominansi

$\mathrm{ni}=$ Jumlah individu spesies ke- $\mathrm{i}$

$\mathrm{N}=$ Jumlah total spesies

Nilai indeks dominansi jenis (D) mempunyai nilai kisaran antara 0-1. Apabila nilai $D$ semakin mendekati nilai 1 berarti semakin tinggi nilai dominansi oleh spesies tersebut. Adapun kriteria dari indeks dominansi jenis yaitu sebagai berikut:

$0,0<\mathrm{D}<0,50=$ Dominansi jenis rendah

$0,50<\mathrm{D}<0,75=$ Dominansi jenis sedang

$0,75<\mathrm{D}<1,0=$ Dominansi jenis tinggi

Persentase tutupan lamun dengan

menggunakan persamaan (Setyobudiandi., $d k k$ 2009),

$C=\frac{\sum\left(C_{i}\right)}{N}$

Keterangan :

$\mathrm{C}=$ Persen penutupan lamun pada setiap

subtasiun

$\mathrm{Ci}=$ Persentase penutupan lamun jenis ke-i

pada tiap plot transek

$\mathrm{N}=$ Jumlah plot transek disetiap substasiun
Tabel 2. Kategori persen tutupan lamun

\begin{tabular}{|l|l|}
\hline Syarat Penutupan & \multicolumn{1}{c|}{ Kesimpulan } \\
\hline $\mathrm{C}>5 \%$ & Sangat jarang \\
\hline $5 \leq \mathrm{C} \leq 25$ & Jarang \\
\hline $25 \leq \mathrm{C} \leq 50 \%$ & Sedang \\
\hline $50 \leq \mathrm{C} \leq 75 \%$ & Rapat \\
\hline$\geq 75 \%$ & Sangat rapat \\
\hline
\end{tabular}

Sumber : Kepmen LH Nomor 200 Tahun 2004

\section{Hasil dan Pembahasan}

Hasil penelitian kepadatan bulu babi pada ekosistem padang lamun di Perairan Desa Langara menunjukkan bahwa kepadatan tertinggi rata-rata terdapat pada bulan terang. Kepadatan tertinggi terdapat di stasiun III dengan nilai $9.03 \mathrm{ind} / \mathrm{m} 2$ dan kepadatan terendah terdapat pada bulan gelap di stasiun II dengan nilai $2.57 \mathrm{ind} / \mathrm{m} 2$.

Hasil penelitian bulu babi pada semua stasiun jenis yang di dapatkan yaitu jenis $D$. savignyi diperoleh kepadatan tertinggi pada saat bulan terang yaitu berkisar $2.12-3.73$ ind $/ \mathrm{m} 2$. Sedangkan jenis T. toreumaticus diperoleh kepadatan terendah yaitu berkisar antara $0.30-0.61 \mathrm{ind} / \mathrm{m} 2$. Pada kondisi bulan gelap kepadatan tertinggi bulu babi juga ada pada jenis $D$. savignyi yaitu berkisar antara 0.27 - $1.4 \mathrm{ind} / \mathrm{m} 2$ dan kepadatan terendah yaitu pada jenis $T$. toreumaticus yaitu dengan $0.3 \mathrm{ind} / \mathrm{m} 2$. Hal tersebut dikarenakan pada saat pengambilan data dilapangan, kondisi bulu babi yang ditemukan pada hampir semua stasiun dalam bentuk mengelompok. Hal ini sesuai pernyataan Aslan (2010) bahwa Diadema hidup mengelompok untuk dapat saling melindungi terhadap ancaman predator.

Kondisi tutupan lamun di Perairan Desa Langara pada kategori rapat ditemukan pada stasiun I dan II, Sementara kondisi tutupan lamun pada stasiun III berada pada kategori sedang. Hal ini berdasarkan keputusan Menteri Lingkungan Hidup Nomor 200 Tahun 2004 bahwa persentase penutupan lamun kategori rapat berada pada kisaran $50-75 \%$ dan kodisi persen penutupan lamun kategori sedang berada pada kisaran 25 - $50 \%$. Dari data persentase penutupan lamun yang dikaitkan dengan kepadatan bulu babi, yaitu pada stasiun I dan II memiliki persen penutupan dalam kategori rapat dimana pada stasiun tersebut kepadatan bulu babi tergolong rendah yaitu berkisar antara $2.75-3.93$ 
ind $/ \mathrm{m} 2$ (bulan gelap) dan $7.03-8.00 \mathrm{ind} / \mathrm{m} 2$ (bulan terang). Sedangkan pada stasiun III persentase tutupan lamun dikategorikan sedang tetapi kepadatn bulu babi yang tinggi yaitu $2.63 \mathrm{ind} / \mathrm{m} 2$ (bulan gelap) dan 9.03 ind $/ \mathrm{m} 2$ (bulan terang). Hal ini sesuai dengan pernyataan (Suryanti dan Ruswahyuni, 2014) bahwa keterkaitan antara bulu babi dan komunitas lamun, kepadatan bulu babi yang tinggi cenderung dijumpai pada area dengan kerapatan lamun yang lebih rendah dikarenakan berkaitan dengan kondisi substrat yang lebih kasar serta perairan yang lebih jernih dan sifat bulu babi sebagai grazer yang memanfaatkan lamun tidak hanya sebagai tempat berlindung tetapi secara langsung memakan daun lamun.

Berdasarkan hasil penelitian, parameter lingkungan di Perairan Desa Lagara masih memungkinkan untuk perkembangbiakan bulu babi, diantaranya suhu, salinitas, $\mathrm{pH}$, dan substrat. Suhu merupakan salah satu faktor yang mempengaruhi keberlangsungan hidup organisme di lautan. Suhu mempengaruhi proses metabolisme pada organisme, selain itu juga berperan dalam proses fisiologi dan respirasi mahluk hidup (Marsh $d k k ., 1986)$. Pengamatan yang dilakukan menunjukkan bahwa suhu Perairan Desa Langara yang diperoleh pada setiap stasiun yaitu berkisar antara $29-30{ }^{\circ} \mathrm{C}$. Nilai kisaran suhu tersebut masih dikategorikan optimal dalam menunjang kehidupan biota perairan. Hal ini sesuai pernyataan Zimmerman $d k k$., (1987), bahwa kisaran suhu optimal untuk pertumbuhan lamun dan organisme benthos berkisar antara $29-30^{\circ} \mathrm{C}$.

Salinitas merupakan konsentrasi ratarata seluruh garam yang terkandung dalam air laut. Nilai salinitas sangat bdderpengaruh terhadap kehidupan organisme di perairan. Hasil penelitian salinitas di Perairan Desa Langara (Tabel 7), hasil pengukuran Salinitas pada penelitian ini yakni kisaran 29 - 31 ppt, hal ini sesuai dengan pernyataan Hutabarat dan Evans (1985), kisaran salinitas yang masih mampu mendukung kehidupan organisme perairan, khususnya fauna makrobentos adalah 15 35 ppt. Menurut Nontji (2005), dinyatakan bahwa sebaran salinitas di laut dipengaruhi oleh berbagai faktor seperti pola sirkulasi air, penguapan, curah hujan dan aliran sungai. Perairan estuaria atau daerah yang terletak di sekitar muara dapat mempunyai struktur salinitas yang kompleks, karena selain merupakan pertemuan antara air tawar yang relatif ringan dan air laut yang relatif berat, juga pengadukan air yang sangat menentukan.

Derajat keasaman atau $\mathrm{pH}$ merupakan logaritma negatif dari konsentrasi ion-ion hidrogen yang terlepas dalam suatu cairan dan merupakan indikator baik buruknya suatu perairan. Hasil pengukuran rata-rata nilai $\mathrm{pH}$ air laut pada setiap stasiun penelitian di Perairan Desa Langara yaitu 8 (Tabel 7). Nilai $\mathrm{pH}$ yang diperoleh pada penelitian ini menunjukkan bahwa $\mathrm{pH}$ cenderung basa dan termasuk dalam kisaran optimum untuk pertumbuhan lamun dan kehidupan markobentos, yaitu $7.0-8.5$ (KLH No.51 tahun 2004).

Tipe substrat pada lokasi penelitian adalah pasir. Tipe substrat sangat mempengaruhi keberadaan hewan benthos terutama bulu babi itu sendiri. Berdasarkan hasil pengamantan, stasiun I memiliki tipe substrat dengan tekstur berpasir kasar, stasiun II memiliki substrat bertekstur pasir sedang dan stasiun III memiliki substrat bertekstur pasir halus. Sehingga pada stasiun I dan stasiun II memiliki persentase tutupan lamun yang rapat dan memiliki bulu babi yang tingkat kepadatannya cukup tinggi pula sedangkan pada stasiun III memiliki persentase tutupan lamun sedang dan memiliki kepadatan bulu babi yang dominan rendah. Umumnya bulu babi mempunyai sebaran habitat yang spesifik dan menyukai substrat yang agak keras, sehingga substrat memiliki pengaruh terhadap keberadaan bulu babi. Selain bulu babi, lamun tempat habitat bulu babi umumnya tumbuh dan subur pada substrat yang keras menurut (Aziz, 1994) bulu babi pada umumnya menghuni ekosistem karang dan padang lamun serta menyukai substrat yang agak keras terutama substrat di padang lamun yang merupakan campuran dari pasir dan dan pecahan karang.

Selain parameter suhu, salinitas, $\mathrm{pH}$, dan substrat faktor kedalaman perairan juga mempengaruhi kepadatan bulu babi. Secara umum bulu babi ditemukan di daerah intertidal yang relative dangkal dan jumlahnya akan semakin menurun apabila kedalaman perairan perairan tersebut semakin meningkat. Pada penelitian ini bulu 
babi di jumpai pada kedalaman $40-100$ $\mathrm{cm}$. Hal ini dikarenakan pada suatu perairan dangkal sumber makanan untuk organisme perairan laut dangkal termasuk bulu babi sangat memadai, sedangkan pada perairan laut dalam kurangnya ketersediaan sumber makanan sehingga menyebabkan bulu babi yang ditemukan banyak terdapat di daerah intertidal.

Bulu babi memiliki siklus hidup yang sangat erat kaitannya dengan ekosistem lamun. Bulu babi memanfaatkan padang lamun sebagai tempat untuk mencari makan, memijah serta sebagai tempat berlindung dari seragan predator. Bulu babi jenis $D$. savignyi menyukai habitat berpasir. Adapun jenis lamun yang menyukai substrat berpasir adalah jenis E.acoroides dan T. hemprichii. Lamun ini tersebar luas di seluruh perairan indonesia dan tumbuh subur pada daerah dengan substrat berpasir. Hal ini sesuai pernyataan Takaendengan dan Azkab (2010), bahwa spesies Enhalus acoroides, Thalassia hemprichii, dan Syringodium iseotifolium adalah spesies tumbuhan lamun yang tumbuh pada substrat pasir dan patahan karang mati, terbuka saat surut, jauh dari pantai dan selalu digenangi air.
Pada umumnya pertumbuhan lamun erat kaitannya dengan kecerahan perairan. Kecerahan merupakan faktor penting bagi proses fotosintesis dan produksi primer dalam suatu perairan. Tingkat kecerahan di Perairan Langara terbilang cukup tinggi, dimana semua stasiun pengamatan sinar matahari dapat menembus hingga dasar perairan. Tingkat kecerahan perairan secara umum pada semua stasiun pengamatan adalah $100 \%$. Tingginya tingkat kecerahan di perairan khususnya pada padang lamun dikarenakan perairan ini umumnya dangkal. Tingkat kecerahan yang tinggi sangat mendukung kehidupan lamun dan fegetasi laut lain untuk melangsungkan proses fotosintesis.

Nilai keanekaragaman bulu babi yang tertinggi diperoleh pada stasiun I yakni 1.64 dan nilai terendah diperoleh pada stasiun III yaitu 1.38. sedangkan nilai indeks keseragaman bulu babi yang tertinggi berada pada stasiun II dengan kisaran nilai keseragaman jenis 2.00 , dan nilai terendah pada stasiun III, yakni 1.77. serta nilai indeks dominansi jenis bulu babi yang tinggi di peroleh pada stasiun III, kisaran nilai dominansi 0.03 .

Tabel 3. Kepadatan bulu babi pada ekosistem padang lamun selama penelitian di Perairan Desa Langara.

\begin{tabular}{|c|c|c|c|c|c|c|c|c|}
\hline \multirow{3}{*}{ No } & \multirow{3}{*}{ Famili } & \multirow{3}{*}{ Jenis } & \multicolumn{6}{|c|}{ Kepadatan $\left(\right.$ ind $\left./ \mathbf{m}^{2}\right)$} \\
\hline & & & \multicolumn{2}{|c|}{ Stasiun I } & \multicolumn{2}{|c|}{ Stasiun II } & \multicolumn{2}{|c|}{ Stasiun III } \\
\hline & & & BG & BT & BG & BT & BG & BT \\
\hline \multirow[t]{3}{*}{1} & Diadematidae & Diadema savignyi & 1.40 & 2.43 & 0.27 & 2.12 & 1.03 & 3.73 \\
\hline & & Echinotrix calamaris & 0.53 & 2.07 & 0.09 & 1.70 & 0.00 & 0.21 \\
\hline & & Diadema setosum & 0.40 & 0.53 & 0.24 & 0.12 & 0.24 & 2.94 \\
\hline \multirow[t]{2}{*}{2} & Echinometridae & Anthocidaris crassispina & 0.47 & 0.00 & 0.30 & 2.06 & 0.24 & 0.42 \\
\hline & & Echinometra mathaei & 0.43 & 0.20 & 0.18 & 0.00 & 0.09 & 0.30 \\
\hline 3 & Toxopneustidae & Tripneustes gratilla & 0.70 & 1.50 & 1.24 & 1.27 & 0.48 & 0.00 \\
\hline \multirow[t]{2}{*}{4} & temnopleuridae & Temnopleurus toreumaticus & 0.00 & 0.30 & 0.00 & 0.00 & 0.30 & 0.61 \\
\hline & & TOTAL & 3.93 & 7.03 & 2.57 & 8.00 & 2.63 & 9.03 \\
\hline
\end{tabular}

Keterangan : $\mathrm{BG}=$ Bulan Gelap, $\mathrm{BT}=$ Bulan Terang

Tabel 4. Keanekaragaman, keseragaman, dan dominansi Bulu babi di ekosistem padang lamun selama penelitian di Perairan Desa Langara

\begin{tabular}{ccccccccc}
\hline & Stasiun I & & \multicolumn{3}{c}{ Stasiun II } & \multicolumn{3}{c}{ Stasiun III } \\
\hline H' $^{\prime}$ & $\mathbf{E}$ & D & H' $^{\prime}$ & E & D & H'$^{\prime}$ & E & D \\
\hline 1.64 & 1.94 & 0.2 & 1.55 & 2.00 & 0.2 & 1.38 & 1.77 & 0.3 \\
\hline \multicolumn{2}{l}{ Keterangan: $H^{\prime}=$} & Keanekaragaman, E & = Keseragaman, D = Dominansi
\end{tabular}


Tabel 5. Persentase tutupan Jenis lamun pada tiap stasiun penelitian di Perairan Desa Langara

\begin{tabular}{|c|c|c|c|c|}
\hline \multirow{2}{*}{ No } & \multirow{2}{*}{ Jenis lamun } & \multicolumn{3}{|c|}{ Persentase Penutupan (\%) } \\
\hline & & Stasiun I & Stasiun II & Stasiun III \\
\hline 1 & Thalassia hemprichii & 31.00 & 36.38 & 27.88 \\
\hline 2 & Enhalus acoroides & 19.50 & 14.5 & 12.13 \\
\hline 3 & Cymodocea rotundata & 0 & 0 & 0.05 \\
\hline 4 & Cymodocea serrulata & 0 & 0 & 1.00 \\
\hline & $\begin{array}{c}\text { Total } \\
\text { Kategori }\end{array}$ & $\begin{array}{l}\text { 50.50 } \\
\text { Rapat* }\end{array}$ & $\begin{array}{c}\mathbf{5 0 . 8 8} \\
\text { Rapat* }\end{array}$ & $\begin{array}{c}\mathbf{4 1 . 0 5} \\
\text { Sedang* }\end{array}$ \\
\hline
\end{tabular}

Keterangan : [*]Kepmen LH Nomor 200 Tahun 2004.

Tabel 6. Hasil pengukuran kualitas Perairan di Desa Langara

\begin{tabular}{lcccccc}
\hline \multirow{2}{*}{ Parameter Kualitas Air } & \multicolumn{2}{c}{ Stasiun I } & \multicolumn{2}{c}{ Stasiun II } & \multicolumn{2}{c}{ Stasiun III } \\
\cline { 2 - 7 } & BG & BT & BG & BT & BG & BT \\
\hline Suhu $\left({ }^{\circ} \mathrm{C}\right)$ & 29 & 30 & 28 & 30 & 28 & 29 \\
Salinitas (ppt) & 30 & 29 & 29 & 30 & 30 & 31 \\
$\mathrm{pH}$ & 8 & 8 & 8 & 8 & 8 & 8 \\
Kecerahan $(\%)$ & 100 & 100 & 100 & 100 & 100 & 100 \\
Kecepatan arus m/detik & 0,35 & 0,23 & 0,27 & 0,31 & 0,45 & 0,24 \\
Substrat & \multicolumn{2}{c}{ Pasir kasar } & Pasir sedang & Pasir halus \\
Kedalaman & $90 \mathrm{~cm}$ & $40 \mathrm{~cm}$ & $60 \mathrm{~cm}$ & $100 \mathrm{~cm}$ & $55 \mathrm{~cm}$ & $100 \mathrm{~cm}$ \\
\hline
\end{tabular}

Keterangan : $\mathrm{BG}=$ Bulan Gelap; $\mathrm{BT}=$ Bulan Terang

Hasil pengukuran suhu air laut pada setiap stasiun yaitu pada bulan gelap dan bulan terang berkisar antara $28-30^{\circ} \mathrm{C}$. Suhu tertinggi yang diperoleh selama penelitian yaitu pada bulan terang sebesar $30{ }^{\circ} \mathrm{C}$. Salinitas pada bulan gelap dan bulan terang menunjukan kisaran salinitas sebesar 29 - 31 ppt. salinitas tertinggi terdapat pada bulan terang yakni sebesar $31 \mathrm{ppt}$ dan $\mathrm{pH}$ yang diperoleh selama penelitian rata-rata 8 pada setiap stasiun pengamatan. Hasil pengukuran kecerahan yakni $100 \%$ pada masing-masing stasiun pengamatan. Nilai kecepatan arus yang diperoleh berkisar antara 0.23-0.31 $\mathrm{m} / \mathrm{det}$, serta tipe substrat yang diperoleh pada masing-masing stasiun yakni pasir kasar, pasir sedang dan pasir halus. Nilai kedalaman yang diperoleh berkisar antara $100-40 \mathrm{~cm}$. Hasil pengukuran kualitas perairan dapat dilihat pada Tabel 7.

Keanekaragaman bulu babi yang diperoleh selama penelitian berkisar antara 1.38-1.64. Keanekaragaman bulu babi tertinggi terdapat pada stasiun I yakni 1.64, serta keanekaragaman terendah terdapat pada stasiun stasiun III yaitu 1.38. keanekaragaman yang didapatkan pada setiap stasiun berdasarkan kisaran stabilitas termasuk dalam kategori sedang. hal ini dikarenakan jumlah total individu jenis yang diperoleh pada stasiun I, II dan III jumlah total yang didapatkan sama banyaknya disetiap stasiun dan penyebaran individu jenisnya memiliki nilai yang tidak terlalu jauh dari setiap stasiun sehingga penyebarannya jumlah jenisnya dapat dikatakan merata. Hal ini sesuai Odum (1993), keanekaragaman jenis dipengaruhi oleh pembagian atau penyebaran individu dalam tiap jenisnya, karena suatu komunitas walaupun banyak jenisnya tetapi bila penyebaran individunya tidak merata maka keanekaragaman jenis dinilai rendah. Rendahnya indeks keanekaragaman juga dipengaruhi oleh letak stasiun yang hampir semuanya terdapat aktivitas manusia. Dari hasil pengamatan yang di dapatkan bahwa ada beberapa jenis bulu babi yang menyukai habitat substrat berpasir kasar dan juga yang menyukai habitat berpasir sedang serta pasir halus.

Keanekaragaman erat kaitannya dengan arus yang sifatnya membawa partikel-partikel halus mengendap didalam substrat, sehingga dapat membuat lamun menjadi lebih subur dan kehadiran bulu babi juga banyak karena adanya sumber makanan di lamun dan menjadi tempat pemijahan. Hasil kecepatan arus di Perairan Desa Langara pada setiap stasiun berkisar antara $0.23-0.45 \mathrm{~m} /$ detik, kecepatan arus yang di dapatkan sesuai dengan yang dikemukakan 
Supriharyono (2007), bahwa keceapatan arus yang terdapat di perairan laut berkisar antara $2-5 \mathrm{~m} / \mathrm{s}$. Faktor habitat dan substrat perairan di duga menjadi faktor utama terkait tingginya keanekaragaman bulu babi, hal ini sesuai yang diutarakan oleh Riniatsih dan Kushartono (2009), bahwa pada tekstur substrat dasar pecahan karang dan pasir memiliki kandungan bahan organik yang lebih rendah dibandingkan dengan tektur substrat dasar lumpur berpasir karena semakin kasar tekstur substrat dasar maka kemampuan dalam menjebak bahan organik akan semakin kecil. Hal ini menunjukkan bahwa ukuran butir sedimen turut mempengaruhi kandungan bahan organik dalam sedimen atau dapat dikatakan semakin kecil ukuran partikel sedimen semakin besar kandungan bahan organik.

Pernyataan Nybakken (1992), bahwa pengendapan partikel bergantung pada arus dan ukuran partikel. Partikel yang lebih besar mengendap lebih cepat dari pada partikel yang lebih kecil dan arus yang kuat mempertahankan partikel tersuspensi lebih lama dari pada arus lemah. Oleh karena itu substrat pada tempat arus kuat akan menjadi kasar (pasir), karena partikel besar yang akan mengendap, sedangkan pada perairan arus lemah, lumpur halus yang akan mengendap.

Stasiun I memiliki tipe substrat pasir kasar dengan persentase tutupan lamun yang rapat dan didominasi lamun jenis $T$. hemprichii dan E. acoroides, hal ini membuat sebagian jenis bulu babi menyukai tempat ini. Pada stasiun I persentase tutupan lamunnya rapat.

Keseragaman bulu babi dalam suatu perairan dapat diketahui dari indeks keseragamannya, Semakin kecil nilai indeks keseragaman organisme maka penyebaran individu tiap jenis tidak sama, hasil keseragaman yang didapatkan selama penelitian berkisar 1.77 - 2.00. Indeks keseragaman akan mencapai nilai maksimum jika kelimpahan individu per jenis menyebar secara merata. Nilai keseragaman tertinggi terdapat pada stasiun II yakni 2.00 dan nilai keseragaman terendah terdapat pada stasiun III yaitu 1.77. Hal tersebut menunjukkan bahwa organisme dalam komunitas tersebut tingkat keseragaman populasi besar sehingga jenis spesies bulu babi cenderung seragam. Hal ini di sebabkan karena stabilnya kondisi lingungan perairan yang mendukung kelangsungan hidup bulu babi sehingga di dapatkan keseragaman tinggi, serta dimana keadaan lingkungan perairan yang masih alami menjadi faktor tingginya tingkat keseragaman.

Hal ini berdasarkan pendapat Odum (1993), apabila nilai indeks keseragaman (E) mendekati $1(\mathrm{E}>0.5)$, maka sebaran individu antara jenis relatif sama, tetapi jika $E$ mendekati $0 \quad(\mathrm{E}<0.5)$, maka terdapat sekelompok jenis spesies tertentu yang jumlahnya relatif melimpah dari pada jenis lainnya. Bulu babi cenderung hidup bergerombol pada suatu perairan, hal ini menunjukan faktor kebiasaan bulu babi untuk berlindung dari serangan predator lain.

Nilai dominansi yang di dapatkan selama penelitian ini yakni berkisar antara 0.2-0.3. Dominansi tertinggi terdapat pada stasiun III yakni 0.3 dan terendah terdapat pada stasiun I dan II yaitu 0.2. Data tersebut menunjukkan bahwa dominansi bulu babi di Intertidal Perairan Desa Langara dalam kondisi rendah. (Fachrul, 2008), menyatakan bahwa apabila suatu biota tertentu di perairan memiliki nilai dominansi mendekati nol, berarti struktur dalam komunitas biota tersebut dalam keadaan stabil, sebaliknya apabila nilai dominansinya 1 , berarti struktur komunitas tersebut labil dikarenakan terjadi tekanan ekologis.

Dominansi organisme, baik jumlah spesies maupun jumlah individu anggota spesies menentukan karakter dari suatu komunitas. Namun, tidak semua organisme mempunyai kontribusi yang sama dalam menentukan karakter komunitas tersebut. Spesies tertentu yang berpengaruh terhadap komunitas baik dari jumlah maupun aktifitasnya. Spesies inilah yang disebut sebagai spesies yang dominan. Hal ini berdasarkan (Dahuri., $d k k$ 2013) bahwa nilai dominansi (D) berada antara 0 sampai 1, jika nilai D mendekati angka 1, maka terdapat sekelompok jenis spesies tertentu yang jumlahnya relatif berlimpah (dominan) sedangkan jika nilai D mendekati angka 0 maka sebaran individu antara spesies merata.

Berdasarkan hasil penelitian di Perairan Desa Langara ialah persentase tutupan lamun didapatkan empat jenis lamun, namun hanya dua jenis yang memiliki presentase tinggi dari setiap stasiun. Ukuran lamun dan juga kerapatan sangat mempengaruhi tutupan lamun. Pada tiap 
stasiun didominasi dua jenis lamun yaitu Thalassia hemprichii dan Enhalus acoroides. Pada stasiun I, dan stasiun II persentase tutupan lamun yang didapat dikategorikan rapat, sedangkan stasiun III persentase tutupan lamunnya dikategorikan sedang. Hal ini berkaitan dengan keanekaragaman bulu babi yang di dapatkan juga berbeda, seperti yang dinyatakan oleh (Fahruddin $d k k$., 2017), tingginya penutupan jenis lamun ini berkaitan dengan ukurannya yang besar, dan kemampuan adaptasinya terhadap tipe substrat berpasir, yaitu dari pasir halus hingga pasir kasar.

Cymodocea serrulata dan Cymodocea rotundata hanya ditemukan pada stasiun III dengan nilai persentase tutupan masingmasing $1.00 \%$ dan $0.05 \%$. Hal ini disebabkan pada saat pengamatan kedua jenis ini ditemukan pada beberapa plot dan ukuran kedua jenis ini kecil kurang lebih 3-5 cm, maka dari itu berdasarkan siklus hidupnya, ada empat kebutuhan dasar bagi kelangsungan hidup lamun yaitu kualitas air laut dan substrat yang sesuai, genangan air laut, serta cahaya matahari (Hemminga dan Duarte, 2000). Kualitas air, yang umumnya ditinjau dari parameter fisika-kimia, seperti cahaya matahari, suhu, salinitas, dan nutrien, akan mempengaruhi proses biokimia dan pertumbuhan lamun (Lee $d k k$., 2007). Lamun merupakan tumbuhan laut yang cepat merespon perubahan lingkungan sehingga jika kondisi habitatnya terdegradasi, maka vegetasi lamun juga akan mengalami degradasi.

\section{Simpulan}

Berdasarkan hasil penelitian yang telah dilakukan di Perairan Desa Langara dapat disimpulkan sebagai berikut:

1. Dari hasil penelitian di Perairan Desa Langara didapatkan tujuh jenis bulu babi dari empat famili yaitu bulu babi jenis $D$. savignyi, E. calamaris, E. mathaei, T. gratilla, A. crissipina, D. setosum, $T$. toreumaticus.

2. Hasil kepadatan bulu babi yang di dapatkan yaitu tertinggi terdapat di stasiun III pada bulan terang dengan nilai $9,03 \mathrm{ind} / \mathrm{m} 2$ dan kepadatan terendah terdapat pada stasiun II pada bulan gelap, dengan nilai 2,57ind $/ \mathrm{m} 2$ dimana keanekaragaman bulu babi selama penelitian juga tertinggi terdapat pada stasiun I yakni 1.64, serta terendah terdapat pada stasiun stasiun III yaitu 1.38 dan Keseragaman bulu babi selama penelitian, tertinggi terdapat pada stasiun II yakni 2.00 serta keseragaman terendah pada stasiun III yaitu 1.77. Dominansi bulu babi yang tertinggi terdapat pada stasiun III yakni 0.3 dan terendah terdapat pada stasiun I dan II yaitu 0.2.

\section{Daftar Pustaka}

Aslan, L., 2010. Bulu Babi (Manfaat dan Pembudidayaanya) Edisi Revisi. Unhalu Press: Kendari.

Aswandy, Inda dan M. Husni Azkab. 2000. "Hubungan Fauna Dengan Padang Lamun". Oseana, Volume XXV, Nomor 3: 19-24. Jakarta: Bidang Jasa dan Ilmiah, Puslitbang OseanografiLIPI. ISSN 0216-1877.

Aziz, A., 1994. Tingkah Laku Bulu Babi Di Padang Lamun. Jurnal Oseana, Volume XXI, Nomor 4, 1996:34-43. ISSN 0216-1877. LIPI. Jakarta.

Dahuri, R., J. Rais, S.P \& M.J. Sitepu. (2013). Pengelolaan umber Daya Wilayah Pesisir Dan Lautan Secara Terpadu. Jakarta: Balai Pustaka.

Fachrul, M.F., (2008). Komposisi dan Moden Kemelimpahan Fitoplankton di Perairan Sungai Ciliwung, Jakarta. Jurnal Biodiversitas, vol.9, No.4, Oktober 2008. Diakses tanggal 12 Juli 2017.

Fahruddin, M, Yulianda, F, Setyobudiandi, I., 2017. Kerapatan dan Penututupan Ekosistem Lamun di Pesisir Desa Bahoi, Sulawesi Utara. Program Studi Pengelolaan Sumberdaya Perairan, Sekolah Pascasarjana IPB, Bogor Jurnal Ilmu dan Teknologi Kelautan Tropis, Vol. 9, No. 1, Hlm. 375-383.

Hutabarat. S. dan Evans. S.M. 1985. Pengantar Oseanografi. Penerbit Universitas Indonesia. 159 hal.

Hemminga, M. A. dan C. M. Duarte. 2000. Seagrass Ecology. Cambridge University Press. Cambridge.

Katili, Abubakar Sidik. 2011. "Struktur Komunitas Echinodermata Pada Zona Intertidal Di Gorontalo". Jurnal Peneitian dan Pendidikan. Volume 8, Nomor 1. Universitas Negeri Gorontalo: Jurusan Biologi, Fakultas MIPA. 
Keputusan Menteri Lingkungan Hidup Nomor 51 Tahun 2004. Tentang Baku Mutu Air Laut

Keputusan Menteri Lingkungan Hidup Nomor 200 Tahun 2004. Kriteria Baku Mutu

Lee KS, Park SR, Kim YK. 2007. Effect of irradiance, temperature, and nutrients on growth dynamics of seagrasses: A Review. Journal of Experimental marine Biology and Ecology. 350 (1 2): 144175 .

Marsh J. A, Dennison, W. C. dan Alberte, R. C. 1986. Effect of Temperature on Photosyintesis and Respiration in Eelgrass (Zostera marina L.) Journal Exp Mar Biol Ecol. 101: 257-267.

Nybakken, J. W. 1992. Biologi Laut Suatu Pendekatan Biologis. PT Gramedia. Jakarta.

Odum, 1993. Fundamental of Ecology. Gajah Mada University Press. Yogyakarta

Riniatsih, I, Kushartono, W, E., 2009. Substrat Dasar dan Parameter Oseanografi Sebagai Penentu Keberadaan Gastropoda dan Bivalvia di Pantai Sluke Kabupaten Rembang. Jurusan Ilmu Kelautan Fakultas Perikanan dan Ilmu Kelautan Universitas Diponegoro Kampus Tembalang Semarang. Ilmu Kelautan, Maret 2009 Vol. 14(1):50-59. ISSN 9853-7291.

Setyobudiandi, I., F. Yulianda., C. Kusmana., S. Hariyadi., A. Damar., A. Sembiring., Bahtiar, 2009. Sampling Dan Analisis Data Perikanan Dan Kelautan. Terapan Metode Pengambilan Contoh Di Wilayah Pesisir Laut. Fakultas Perikanan Dan Ilmu Kelautan. IPB. Bogor.

Suryanti, Ruswahyuni., 2014. Perbedaan kelimpahan Bulu babi (echinoidea) pada ekosistem karang dan lamun di pancuran belakang, Karimunjawa Jepara.

http://ejournal.undip.ac.id/index.php/sa intek. Jurnal Saintek Perikanan Vol. 10 No.1 : 62-67. Universitas Diponegoro: Program Studi Manajemen Sumberdaya Perairan, Jurusan Perikanan Fakultas Perikanan dan Ilmu Kelautan.

Supriharyono. 2007. Konservasi Ekosistem Sumber Daya Hayati di Wilayah
Pesisir dan Laut Tropis. Yogyakarta: Pustaka Pelajar.

Steven, Nasution, S, Tamrin., 2014. Density and distribution pattern of sea urchin population (diadema setosum) on coral reef (reef flat) at setan island. Student in Fisheries and Marine Sciences Faculty, Riau University.

Takaendengan, K dan Azkab, M.H, 2010. Struktur Komunitas Lamun di Perairan Pulau Talise, Sulawesi Utara. Jurnal Oseanografi dan Limnologi-LIPI, Sulawesi Utara. Vol.36. No 1: 85-95.

Tangke, Umar. 2010. Jurnal ilmiah agribisnis dan perikanan (agrikan Ummu-Terate). Volume 3 edisi 1. Ternate. Staf pengajar faperta Ummu.

Tupan, J., Silaban, B.B., 2017 Karakteristik Fisik-Kimia Bulu babi Diadema setosum dari beberapa Perairan Pulau Ambon. Jurnal Triton Volume 13, Nomor 2 : 71-78. Jurusan Teknologi Hasil Perikanan Fakultas Perikanan dan Ilmu Kelautan Universitas Pattimura. ISSN 1693-6493.

Zimmerman RC, Smith RD, Alberte RS. 1987. Is growth of the Eelgrass nitrogen limited a numerical simulation of effect of light and nitrogen on the growth dynamics of Zostera marina. Marine Ecology Progress Series 41:167-176. 